\title{
The Generic skills challenge for higher education institutions: Experience of public universities in Chile
}

\author{
Luis Sandoval and María Ormazábal*
}

doi: http://dx.doi.org/10.18543/tjhe-8(2)-2021pp55-83

Received: 3 March 2020

Accepted: 5 March 2021

\begin{abstract}
In recent decades in Chile, generic skills have been made explicit in the graduation profiles and curricula of all programs of higher education institutions, following global trends that relate to labor market expectations on the employability of graduates. The institutional characteristics, mission, educational model, and institutional seal condition the choice of the generic skills that are developed. There are no current standards for the process of definition of generic skills sets in the various programs for the different universities. The same is true for the modality of implementation for them. The present article has the purpose of contributing to the knowledge of both the definition and implementation of generic skills inside higher education institutions in Chile. This process becomes relevant in the context of the new demands of students and graduates who face additional employment challenges.
\end{abstract}

Keywords: generic skills; curriculum; generic competences; management education; Chilean universities

\section{Introduction}

In recent decades in Chile, generic skills have been highlighted and made explicit in the graduation profiles and curricula of virtually all programs of

* Luis Sandoval (1sandoval@utem.cl) works at the Universidad Tecnológica Metropolitana (Chile). His interest areas are educational policies, impact evaluation, higher education and employment.

* María Ormazábal (mormazabal@utem.cl) works at the Universidad Tecnológica Metropolitana (Chile). Her interest areas are educational policies, generic competences, impact evaluation, higher education and employment.

More information about the authors is available at the end of this article.

Acknowledgements: The authors thank the Universidad Tecnológica Metropolitana del Estado de Chile for providing the necessary funds to carry out this study, through Project L11710. They also thank Sofía Sandoval, for her assistance and comments.

Disclosure statement: No potential conflict of interest was reported by the authors. 
higher education institutions, following global trends that relate to labor market expectations on the employability of graduates. The influence of globalization, job insecurity, massification of higher education, and the shift towards a knowledge-based economy are also intervening factors in the concern for the employability of graduates and relevant generic skills. ${ }^{1}$ In addition, Chilean educational policies provided resources and incentives for highereducation institutions to address training designs based on competences. ${ }^{2}$ This process has been framed in an effort of the institutions to differentiate in a strongly competitive higher education market.

The institutional characteristics, mission, educational model, and institutional seal determine the choice of the generic skills that are developed, varying in quantity, levels of achievement, and modalities of curricular implementation. However, there are no studies reviewing the selection and implementation of generic skills in Chilean universities from a comparative perspective.

The purpose of the present article is to contribute to the knowledge of the definitions and modalities of implementation that public institutions have adopted in relation to generic skills. To do so, the process of adaptation of public universities is described and contextualized from both a global and local perspective.

\section{Generic skills in higher education}

The debate on generic skills in Europe, the USA, Australia, and other countries is already more than three decades old. It is certainly not a new topic of discussion, even when the use of the term "competence" is. In fact, just as Diaz Barriga ${ }^{3}$ points out, it is possible to trace the essence of the dichotomy between encyclopedic knowledge and solution-oriented thinking back to the XVII century. Nevertheless, it was only in the XX century, when the schools

${ }^{1}$ Cristina Sin, and Guy Neave, "Employability Deconstructed: Perceptions of Bologna Stakeholders", Studies in Higher Education, 41, no. 8, (11 de noviembre 2014), 1447-1462, https://doi.org/10.1080/03075079.2014.977859.

${ }^{2}$ Roxana Pey and Sara Chauriye, Innovación Curricular en las Universidades del Consejo de Rectores 2000 - 2010. (Chile: Consejo de Rectores, noviembre 2011), 91, https:// sct-chile.consejoderectores.cl/documentos_WEB/Innovacion_Curricular/2.Informe_ INNOVACION_CURRICULAR.pdf.

3 Ángel Díaz-Barriga, "Competencias en educación. Corrientes de pensamiento e implicaciones para el currículo y el trabajo en el aula", Revista Iberoamericana de Educación Superior (ries), 2, no. 5, (México, unam-iisue/Universia, 2011), 3-24, http://ries.universia.net/ index.php/ries/article/view/126. 
of thought better defined their stances, with North American pragmatic pedagogy in the basic education level as an example of this movement.

Higher education was belatedly impacted by this discussion. It was not until the eighties that a favorable tendency to orient the curriculum to the needs of the labor market and social context started to brew in European circles. The Bologna Declaration made a referent to go forward in this direction. Studies that provided an empirical base were given an impulse under the suspicion that university and academia was not fully connected to the labor market demands. The DESECO, REFLEX and PROREFLEX projects later confirmed this hypothesis.

The Tuning project came to offer a methodology to innovate the curriculum and connect higher education to the needs given by social context. This methodology was quickly adopted by Latin American countries, Chile among them. ${ }^{4}$ The following components were particularly popular: (1) Generic competences; (2) Subject specific competences; and (3) Academics credits. ${ }^{5}$ In respect of generic competences, there has been no consensus reached about what it fully encapsulates, sowing doubt in some authors over the convenience of focusing solely on skills. ${ }^{6}$

The controversy around generic competences has stressed higher education institutions, pressured by the government and the labor market to respond to employability requirements. In fact, current career paths show that, despite living in a society dominated by knowledge, higher education does not constitute a guarantee of insertion and employability. This situation has generated uncertainty regarding the quality of graduates, questioning the role of higher education in the formation of transferable generic skills. These are considered essential in the current labor market to increase individual employability. ${ }^{89}$ In response to this, universities have sought

${ }^{4}$ Pey and Chauriye: "Innovación Curricular”, 20.

5 Julia González, and Robert Wagenaar, eds., Tuning educational structures in Europe: Final Report. Phase One (Bilbao: University of Deusto and University of Groningen, 2003), 22.

${ }^{6}$ Richard Harris and Barbara Ormond, Historical knowledge in a knowledge economy what types of knowledge matter? Educational Review, 71, no. 5, (25 de abril de 2018), 564580. https://doi.org/10.1080/00131911.2018.1462764.

7 Scott A. Hurrel, "Rethinking the soft skills deficit blame game: Employers, skills withdrawal and the reporting of soft skills gaps", Human Relations, 69, no. 3, (2016), 605-628.

${ }^{8}$ Marilyn Clarke, "Rethinking Graduate Employability: The Role of Capital, Individual Attributes and Context", Studies in Higher Education, 43, no. 11 (23 de febrero de 2017), 1923-1937, https://doi.org/10.1080/03075079.2017.1294152.

9 Johanna Elizabeth Crossman and Marilyn Clarke, "International experience and graduate employability: stakeholder perceptions on the connection”, Higher Education, 59, (2010), 599-613. https://doi.org/10.1007/s10734-009-9268-z. 
strategies to increase their role in the development of generic skills, a process from which some considerations arise. However, the problem does not seem easy to solve, in light of the evidence and results. ${ }^{10,11}$

First, by virtue of the link between generic skills and employability, the first challenge is to adequately define the concept of employability of graduates. Despite the elapsed time, there is no clear consensus on this. ${ }^{12}$ In LatinAmerica, generic skills were defined as those that "(...) identify the shared elements, common to any degree, such as the ability to learn, to make decisions, to design projects, interpersonal skills" by the report of the Tuning Latin America Project. 27 generic skills common to any profession were identified. ${ }^{13}$

A second aspect is to establish how important generic skills really are. Balcar ${ }^{14}$, Heckman, Stixrud and Urzua ${ }^{15}$ and Abaida, Lakrari and Abdouni ${ }^{16}$ have provided strong evidence that in the determination of salaries, generic skills are as or more important than specific skills.

Thirdly, it is important to define which ones are the generic skills valued by employers. The underlying hypothesis is that those who have a professional degree and have also managed to develop the skills that better respond to the needs of employers would have a more expeditious transition towards job placement, which is considered an indicator of the relevance and quality of the training. ${ }^{17}$ At the same time, it is interesting to note that the valuation of skills by employers may not coincide with that of the students.

${ }^{10}$ Fatima Suleman and Ana María Costa, "The employability skills of graduates and employers' options in Portugal: An explorative study of anticipative and remedial strategies," Education + Training, 60, no. 9 (2018), 1097-1111, https://doi.org/10.1108/ET-10-2017-0158.

${ }^{11}$ Fraser J. Scott, Pauline Connell, Linda A. Thomson and Debra Willison, "Empowering students by enhancing their employability skills", Journal of Further and Higher Education, 43, no. 5 (2017), 692-707, https://doi.org/10.1080/0309877X.2017.1394989.

${ }_{12}$ Clarke, "Rethinking" (2017), 1923-1937.

${ }_{13}$ Pablo Beneitone, César Esquetini, Julia González, Maida Marty Maletá, Gabriela Siufi and Robert Wagennar, Informe Final del Proyecto Tuning América Latina: Reflexiones y perspectivas de la Educación Superior en América Latina. (Bilbao, España: Universidad de Deusto \& Universidad de Groningen, 2007), 430, http://tuning.unideusto.org/tuningal.

${ }^{14}$ Jiří Balcar, "Is it Better to Invest in Hard or Soft Skills?" The Economic and Labour Relations Review 27, no. 4 (2016), 453-470, https://doi.org/10.1177/1035304616674613.

15 James J. Heckman, Jora Stixrud and Sergio Urzúa, "The Effects of Cognitive and Noncognitive Abilities on Labor Market Outcomes and Social Behavior", Journal of Labor Economics, 24, no. 3 (2006), 411-482, http://www.jstor.org/stable/10.1086/504455.

${ }^{16}$ Abdellah Abaida, Youssef Lakrari and Abdeljabbar Abdouni, "An examination of the relationship between competences and wages of higher education graduates: Evidence from Morocco", Tuning Journal for Higher Education, 5, no. 1, (30 de noviembre de 2017), 75-100 http://dx.doi.org/10.18543/tjhe-5(1)-2017pp75-100.

${ }_{17}$ Lee Harvey, "Defining and Measuring Employability", Quality in Higher Education, 7, no. 2 (2010), 97-109, http://dx.doi.org/10.1080/13538320120059990. 
Different studies have concluded that there would be a mismatch between the skills obtained in higher education and those demanded by the productive sector. ${ }^{18,19,20}$ In this way, the need to identify a set of generic skills in the graduation profiles of any professional degree taught by a university institution arises. This assessment is dynamic. According to the World Economic Forum the most sought-after generic skills in 2015 may not be the same in $2023 .{ }^{21}$ For example, this body estimates that the skills of analytical thinking and innovation, active learning and learning strategies, creativity, originality, and initiative, technology design, and programming, critical thinking and analysis, among others, will be the most valued by 2023 .

Other authors have identified that fundamental skills include communication, teamwork, problem solving, and critical and innovative thinking, creativity, self-confidence, ethical understanding, lifelong learning ability, ability to cope with uncertainty, and willingness to accept responsibilities. ${ }^{22,23,24,25,26,27}$

Another aspect that adds to the above is the increasing automation of industry and services. This occurrence will imply the loss of importance of

18 Bárbara Fenesi and Faria Sana, "What is your degree worth? The relationship between post-secondary programs and employment outcomes", Canadian Journal of Higher Education, 45, no. 4 (2015), 383-399, http://journals.sfu.ca/cjhe/index.php/cjhe/article/view/183604/pdf_48.

19 Anthony P. Carnevale, Cheah Ban and Jeff Strohl, Hard Times: College Majors, Unemployment and Earnings: Not All College Degrees Are Created Equal. (Georgetown: Georgetown University, 2013), 3-17, http://hdl.handle.net/10822/559308.

${ }_{20}$ John Robst, "Education and job match: The relatedness of college major and work", Economics of Education Review, 26, no. 4 (2007), 397-407, https://doi.org/10.1016/j. econedurev.2006.08.003.

${ }^{21}$ World Economic Forum, The Future of Jobs Report (World Economic Forum, 2018), 9-13, https://www.weforum.org/reports/the-future-of-jobs-report-2018.

22 Clarke, "Rethinking”, 1923-1937.

${ }^{23}$ Tim Moore, and Janne Morton, “The Myth of Job Readiness? Written Communication, Employability, and the 'Skills Gap' in Higher Education," Studies in Higher Education, 42, no. 3 (2017), 1-19, https://doi.org/10.1080/03075079.2015.1067602.

${ }^{24}$ Senia Kalfa and Lucy Taksa, "Cultural Capital in Business Higher Education: Reconsidering the Graduate Attributes Movement and the Focus on Employability", Studies in Higher Education, 40, no. 4, (2015), 580-595, https://doi.org/10.1080/03075079.2013.84221.

25 Jane Andrews and Helen Higson, "Graduate Employability,'Soft Skills' Versus 'Hard' Business Knowledge: A European Study”, Higher Education in Europe, 33, no. 4 (2008), 411-422, https://doi.org/10.1080/03797720802522627.

${ }^{26}$ Dominique Rychen and Laura H. Salganik (ed.), Key Competences for a Successful Life and Well-Functioning Society, (Göttingen, Germany: Hogrefe \& Huber Publishers, 2003), 181-186.

${ }^{27}$ Lee Harvey, William Locke, and Alistair Morey, Enhancing employability, recognizing diversity Making links between higher education and the world of work (London: Universities UK, 2002), 10-12. 
various skills, as certain tasks are automated ${ }^{28}$ In this context, the OECD has considered identifying the relevant skills in 2030, amid special challenges in environmental, social, and economic issues. ${ }^{29}$ They identify three areas of competence that will be key to face the challenges identified: creating new value (sustainable development), reconciling tensions and dilemmas, and taking responsibility.

In Europe and Latin America, universities have approached training in generic skills based on the approach installed by the Bologna Process and concretized through the Tuning-Europe project, initiated in 2001 with 175 European universities. ${ }^{30}$ The countries of Latin America, from 2003, begin their own itinerary with the Tuning-Latin America project. ${ }^{31}$

In Chile, the Tuning Project had an important effect on the higher education system, almost completely adopting its postulates. The adaptation of the educational projects of the institutions to Tuning materialized through a process called curricular innovation. In the decade between 2000-2010, numerous curricular innovation initiatives were developed under this financing line, the common aspects being: (1) the definition of graduation profiles as an articulating element of the degrees and degrees, (2) student centrality and learning time (3) integrative curriculum structure, and (4) training process organized in generic and specific skills. ${ }^{32}$ In fact, Chilean traditional universities started this process of curricular innovation through funds coming from the higher education's quality improvement projects (MECESUP), financed by the Education Ministry. All the universities considered in the present study have implemented their curricular innovation process with state funding; funding that considered i) initial implementation of this new curriculum focused on learning outcomes and tuned to the labor market's and social context's needs, and ii) the definition and initial

28 Jacques Bughin, Eric Hazan, Sudan Lund, Peter Dahlström, Anna Wiesinger, \& Amresh Subramaniam, Skill Shift Automation and the Future of the Workforce, (McKinsey Global Institute, 2018), 1-49, https://www.mckinsey.com/ /media/McKinsey/Featured\%20 Insights/Future $\% 20$ of $\% 20$ Organizations/Skill\%20shift $\% 20$ Automation $\% 20$ and $\% 20$ the $\% 20$ future $\% 20$ of $\% 20$ the $\% 20$ workforce/MGI-Skill-Shift-Automation-and-future-of-theworkforce-May-2018.ashx.

${ }^{29}$ OECD, The future of education and skills. Education 2030, (OCDE, 2018), 23. https:// www.oecd.org/education/2030/E2030\%20Position\%20Paper\%20(05.04.2018).pdf.

${ }^{30}$ Alberto Amaral, Guy Neave, Christine Musselin and Peter Maassen, European Integration and de Governance of Higher Education and Research (Springer, 2009), 3-58.

${ }^{31}$ Julia González, Robert Wagenaar and Pablo Beneitone, "Tuning - América Latina: un proyecto de las universidades” Revista Iberoamericana de Educación, 35 (2004), 151-164, https://rieoei.org/historico/documentos/rie35a08.pdf.

32 Pey and Chauriye, Innovación Curricular, 36. 
implementation of a system for academic credit transfer (SCT-Chile, compatible with the European ECTS) that provides students national and international mobility and advancement towards the articulation of different level of higher education.

The National Accreditation Commission in Chile also states that any curriculum should explicitly contemplate general learning objectives, such as communication, critical thinking, problem solving, social interaction, selflearning and personal initiative, training and ethical consistency, globalized thinking, citizenship training, and aesthetic sensibility. ${ }^{33}$

Finally, it should be noted that in 2018, two laws were passed in Chile: one for Higher Education ${ }^{34}$ and another for public universities. ${ }^{35}$ These laws, among other matters, define a set of generic skills that institutions in general, and public institutions in particular, should contemplate in their training processes. There, it is defined that it is the function of universities to seek the integral and ethical training of people, oriented to the development of autonomous and critical thinking. This encourages them to participate and contribute actively in the different areas of life in society, according to their talents, interests, and abilities. In the case of the law for public universities, it is specified that as a constitutive and inescapable element of their mission, the public universities must train people with a critical and reflective spirit that promotes rational dialogue and tolerance, and that contributes to forge a citizenship inspired by ethical, democratic, civic and social solidarity values, respectful of the native population and the environment. In regions with more abundant native population, the local public universities must include in their mission the recognition, promotion, and incorporation of their worldview.

The current public universities in Chile were created from the regional headquarters of two large government-owned universities: University of Chile and State Technical University. During the Military Government (1973-1989), a reform of the higher education system was carried out, creating 14 public universities in the period. During the last government of Mrs. Bachelet (2014-2017) two new regional universities were created.

In the Chilean higher education system, there has been a growing differentiation and competition between public and private universities. The

${ }^{33}$ Comisión Nacional de Acreditación, Criterios para la acreditación de carreras. (Santiago, Chile, Comisión Nacional de Acreditación, 2016), 1- 16. https://www.cnachile.cl/ Criterios\%20y\%20Procedimientos/DJ\%20009-4\%20Criterios.pdf.

${ }^{34}$ Ley $\mathrm{N}^{\circ}$ 20.901, Diario Oficial de la República de Chile, (Chile: Santiago; May 11, 2018)

${ }^{35}$ Ley $\mathrm{N}^{\circ}$ 20.904, Diario Oficial de la República de Chile, (Chile: Santiago, May, 25, 2018) 
latter do not receive subsidies from the government, unlike the former. However, private universities have led the growth of seats, and the expansion of the coverage of university education is largely due to their actions. On several occasions, some private universities have been accused of acting with profit criteria, which is prohibited by Chilean law. Others have been closed by the government for not ensuring quality service. ${ }^{36}$

\section{Data}

The population studied are public universities. It should be noted that there are 18 universities of this type in Chile.

The studied population is traditional universities. It is important to note that in Chile, there is only 18 higher education institutions that belong to this group. Out the 18, two of them have been founded recently and do not count with graduated alumni as of the moment in which the present study was conducted. For this reason, they were not considered.

The information used in the study came from the following sources:

a) Secondary sources: oficial documents from each institution, such as the education model, complementary documents that describe the generic competences, and information available in institutional websites.

b) Structured interviews: A questionnaire was applied to teaching directors of each one of the 18 universities. The questionnaire comprehended 16 closed-ended questions and three open-ended ones. The main topics considered were: i) identification of the main referents used to define the generic competences of the institution, ii) Curricular Implementation modality of generic competences, iii) Distinction between generic competences and institutional seal, iv) changes made to the generic competences since their initial definition, v) Identification of communication and improvement mechanisms regarding generic competences, vi) Perception of the understanding level of generic competences among members of the universities's teaching community, and vii) Monitoring and evaluation mechanisms for generic competences. The validity of this instrument was evaluated by an external party.

The results obtained were analyzed in contrast with a documental analysis to give more robust results.

${ }^{36}$ María O. Monckeberg, Con fines de lucro. La escandalosa historia de las universidades privadas de Chile, (Santiago, Chile, Debate, 2013). 
Data analysis:

a) Documental review: In a first stage, this analysis allowed to identify the generic competences that each institution declared in their respective education model, so later they could be classified following a code of identification that allowed to unify criteria and names. This method permitted the competences found to be quantified and grouped according to a typology made by the authors of the present study. The typology was based on the most used concepts by the institutions, producing a standardized denomination for each generic competence.

In the second stage, a data base with the following variables was constructed.

- University's name

- Denomination used by the institution to refer to a specific competence. This was considered to be necessary, since not all institutions used the same concepts. Seal, attribute, skill, and competence are used indiscriminately.

- List of attributes, skills, competences, seal, or any other identified by the institution that alluded to generic competences.

- Standardized denomination for each generic competence.

- Standardized codification for each generic competence by the investigators.

- Definition of each generic competence given by the respective institution.

- Declaration of institutional seal.

- Sources of information transparency.

- Date of the source

The descriptive analysis of the compiled data base considered the frequency of each generic competence declared as part of the institutional seal and was later compared to the total amount of generic competences found across all institutions.

b) Structured interview: the resulting data was processed in Excel to analyze the frequency of the observed variables, this in lieu of the small sample size. This data was used as base to tackle the questions in the semi-structured interview.

c) Semi-structured interview: the data obtained from these interviews was analyzed with the content analysis technique with the goal of 
identifying the categories that surged spontaneously from the interviewed directors' discourse. Finally, all information sources were triangulated to describe the results.

Table 1 shows participation of institutions according to the instrument applied and the data supplies by each one of them.

Table 1

Type of information source and the data each provided

\begin{tabular}{|c|c|c|c|}
\hline $\begin{array}{l}\text { Information } \\
\text { source type }\end{array}$ & $\begin{array}{c}\text { Documental } \\
\text { review }\end{array}$ & Structured interviews & $\begin{array}{l}\text { Semi-structured } \\
\text { interviews }\end{array}$ \\
\hline $\begin{array}{l}\text { Number of } \\
\text { universities }\end{array}$ & 18 universities & 18 universities & 13 universities \\
\hline $\begin{array}{l}\text { Data provided } \\
\text { by each source } \\
\text { of information }\end{array}$ & $\begin{array}{l}\text { i) number } \\
\text { of generic } \\
\text { competences } \\
\text { by institution, } \\
\text { ii) Names of } \\
\text { each generic } \\
\text { competence } \\
\text { given by each } \\
\text { institution } \\
\text { iii) Generic } \\
\text { competences' } \\
\text { definition } \\
\text { by each } \\
\text { institution }\end{array}$ & $\begin{array}{l}\text { i) Main referents } \\
\text { used to define } \\
\text { generic competences } \\
\text { in the institution's } \\
\text { identification. } \\
\text { ii) Curricular } \\
\text { implementation of } \\
\text { generic competences' } \\
\text { modality. } \\
\text { iii) Distinction between } \\
\text { generic competences and } \\
\text { institutional seal } \\
\text { iv) Modification made to } \\
\text { the generic competences } \\
\text { since they were first } \\
\text { defined } \\
\text { v) Identification of the } \\
\text { diffusion mechanism } \\
\text { and teaching further } \\
\text { development in the topic } \\
\text { of generic competences } \\
\text { vi) Level of knowledge } \\
\text { available about generic } \\
\text { competences's perception } \\
\text { in the university's } \\
\text { community. } \\
\text { vii) Mechanisms to follow } \\
\text { up and asses generic } \\
\text { competences }\end{array}$ & $\begin{array}{l}\text { Further } \\
\text { insight on } \\
\text { the following } \\
\text { aspects: } \\
\text { i) curriculum, } \\
\text { ii) organization, } \\
\text { iii) budget, } \\
\text { iv) assessment }\end{array}$ \\
\hline
\end{tabular}




\section{Results}

\section{IV.1. Generic skills' selection process}

All institutions have used participatory mechanisms, which consist of consultations with the various institutional bodies, clusters, workshops with a wide call, academic representatives' commissions, and, in some cases, external experts. In addition, all institutions have considered consultation with employers and graduates. Only in some institutions considered student participation as well.

The use of participatory mechanisms implies an important investment of time. In this sense, there is a coincidence in the institutions that reaching agreements demanded, at least, one year of work. All the institutions participating in the study have selected generic skills through commissions made up of scholars and, in some cases, also external experts. The participation of students in the selection of generic skills was mentioned only by the minority of the institutions.

The following criteria were indicated by the institutions as those used to define generic skills:

- Labor market requirements (Information from graduates and employers).

- The educational model of the institution.

- Institutional mission.

- Institutional values.

- Agreements between universities.

- Latin American Tuning Project.

- Student admission profile.

- Demands of students raised in protests.

- Institutional accreditation requirements.

- Institutional seal.

Among these criteria, the ones most frequently mentioned correspond to the institutional mission, institutional seal, educational model, and demands of the working environment.

The result of the commissions' work, as expressed by all the universities, was collected in reports that recommend a set of generic skills, which were approved by academic governing bodies of the university. Finally, generic skills are published in the curriculum documents of the respective programs, specifically in the graduate profile and additionally in educational model documents. Subsequently they are disseminated in advertising intended to attract applicants. 
The process involved a significant investment of time. In the present case, it took around a year. This time frame includes the process of consulting employers and graduates.

\section{IV.1.1. Generic skills}

Universities use different denominations to refer to generic skills. They are called institutional seal, formative seal, identity seal, intellectual abilities, personal qualities, instrumental competences, among others.

The studied universities identify 117 generic competences. Table No. 1 presents some general data.

\section{Table 2}

Number of generic competences of the 18 public universities.

\begin{tabular}{|l|c|}
\hline Total & 117 \\
\hline Average per institution & 6.5 \\
\hline Mode & 6 \\
\hline Minimum per institution & 3 \\
\hline Maximum per institution & 13 \\
\hline
\end{tabular}

Source: Educational models of the universities of the State of Chile.

The quantity of generic competences declared by the 18 traditional universities amount to 117 . The big majority of them refer to the same skill or attribute with different names. Because of this, a standardized denomination system was used to better classify them.

Table 1 describes measures of key trends presented by the generic competences compilated. As one can observe, institutions have a median of 6,5 generic competences. The data is further described in table 2 . The number of generic competences since they were selected and defined by the respective institution has experimented changes during the process of reformulation in most universities. In this process, a tendency to reduce the initial number and better define them has been highlighted. These adjustments have happened considering new teaching plans that consider the actual capacity the institution has to pass down these competences to their students. In other words, a criterion of efficacy has predominated, hoping to generate a more ambitious and successful profile for graduates. 
Finally, the modification in terms of quantity and definition of generic competences have happened in the context of upgrades to the formative models.

Table 3

Distribution of generic skills in public universities

\begin{tabular}{|l|c|c|}
\hline \multicolumn{1}{|c|}{ Skills identified by the institutions } & Frequency & $\%$ \\
\hline Effective communication & 14 & $77,8 \%$ \\
\hline Ethics & 11 & $61,1 \%$ \\
\hline Teamwork & 11 & $61,1 \%$ \\
\hline Autonomous learning & 10 & $55,6 \%$ \\
\hline Social responsibility & 10 & $55,6 \%$ \\
\hline English & 8 & $44,4 \%$ \\
\hline Information and communication technologies & 7 & $38,9 \%$ \\
\hline Innovation and entrepreneurship & 6 & $33,3 \%$ \\
\hline Leadership & 6 & $33,3 \%$ \\
\hline Critical Thinking & 4 & $22,2 \%$ \\
\hline Commitment to quality & 3 & $16,7 \%$ \\
\hline Sustainability & 3 & $16,7 \%$ \\
\hline
\end{tabular}

Abstraction, analysis and synthesis, ability to apply knowledge into practice, consideration of the global context, mathematical skills, social skills, information management, and troubleshooting were mentioned twice.

Adaptability, research capacity, active citizenship, regional commitment, disciplinary knowledge, disciplinary innovation, multiculturalism, results orientation, technology, and tolerance were mentioned once.

Source: Educational models of the universities of the State of Chile.

It is found that there is a coincidence in a subset of generic skills that are the most frequent. Effective communication, teamwork, ethics, social responsibility, and autonomous learning. This coincidence has happened without the institutions having reached a formal agreement. This demonstrates the cross-cutting nature of generic skills and convergence in graduation profiles.

Regarding the definition of these competences, in most cases a document stating the official definition, their progression levels and respective goals, 
exists. In this sense, while many common elements exist across institutions and competences, each university has gone through this process in an independent manner. This happens because there is no consensus or sole way of understanding most of these concepts, like effective communication, teamwork, or leadership, for example. In consequence, the direction given to each competence answers to the university's point of view and perspective. In fact, the Latin America Tuning Project identifies a group of 27 generic competences, but does not provide operationalization, leaving this part to the institutions.

Concerning the evolution of generic skills since they were selected and defined by the institutions, the majority have experienced reformulation processes in which a tendency to decrease their initial quantity stands out. The evolution of the number of generic skills since they were selected and defined by the institutions, 7 of 13 have undergone reformulation processes with respect to those declared in the first version of the educational model. In these reformulations, a tendency to decrease the initial amount of these competences is highlighted, as well as to specify their definition. The argument that supports these adjustments is the real capacity of a curriculum to effectively train in a set of generic skills that students must demonstrate. That is, the effectiveness criterion of the training process has been privileged, after experimenting with a more ambitious graduation profile, in the sense of the number of generic competences and how cross curricular they are in the undergraduate programs of each institution.

The modifications in terms of number and definition of generic skills have been made in the context of updates of the educational models.

\section{IV.1.2. Institutional seal}

An aspect that is important to consider is the so-called institutional seal, as it is often confused with generic skills. The institutional seal usually represents a subset of the generic skills, which are understood by the institutions as the identity of the training and consequently, directly linked to the university's mission.

$50 \%$ of the total generic skills declared by the studied institutions are indicated as an institutional seal, as shown in the following table.

The difference between a generic competence and a "seal" competence is in the emphasis given to the latter ones both in the teaching process and institutional extracurriculars oriented to reinforce them. In fact, it is each university's goal to have alumni recognized by this seal, when compared to graduates from other institutions. 
Institutional seal competences have been incorporated only recently in higher education curricula, therefore there is not enough evidence on this topic. Many authors agree about the complexity that implies evaluating the achievement of these competences inside a formative process, particularly in terms of acquiring evidence of this achievement. One way to do so is interviewing the employers of their graduates. ${ }^{37,38}$ This kind of practices has been installed as a quality insurance mechanism in the face of accreditation processes at the national level..$^{39}$

\section{Table 4}

Generic competences declared an institutional seal by the universities of the State of Chile

\begin{tabular}{|l|c|}
\hline \multicolumn{1}{|c|}{ Generic competences declared formative seal } & Frequency \\
\hline Yes & 58 \\
\hline No & 59 \\
\hline Total & 117 \\
\hline
\end{tabular}

Source: Own elaboration based on institutional educational models.

The "seal" generic skills with greater presence in public institutions are social responsibility, ethics, effective communication, teamwork, communication technologies, and English. Of the 29 generic skills identified in this study, 22 of them are those that make up the institutional seal (75.9\%).

What has been observed in the studied universities, is that the institutional seal has become a new component in the training processes. It has given rise to specific subjects within the curriculum, its incorporation into disciplinary subjects, and even the design of extracurricular initiatives to support training in the generic skills that make up the institutional seal. Accordingly, the evidence contributed by the present study shows that the 13 universities have all designed curricular activities specifically to promote the development of

37 Claude Lessard, "La réforme du curriculum québécois et son difficile atterrissage", Revue internationale d'éducation de Sèvres, 73, (2016), 95-106, http://journals.openedition. org/ries/5623.

38 Alejandro Sepúlveda Obreque, Margarita Opazo Salvatierra, Danilo Díaz-Levicoy. "Competencias sello en la universidad: promoción y evaluación en Pedagogía Básica". Cuad. Investig. Educ., 9, no. 1, (Montevideo, 2018), 35-46.

39 Comisión Nacional de Acreditación, Criterios para la acreditación de carreras, (Santiago, Chile, 2016), https://www.cnachile.cl/Criterios\%20y\%20Procedimientos/DJ\%20 009-4\%20Criterios.pdf. 
the seal competences, ensuring in this way that they are present in all formative programs and therefore guaranteeing all their students have received the training. A group of institutions have chosen a mixed modality, meaning they combine extracurricular activities with a transversal training throughout the whole curriculum.

Another interesting aspect of the institution's seal is the fact that this acquires different nuances depending on the geographical location of the institution. It is the case of regional (as opposed to those in the capital) universities where a link with the region's characteristics can be found. For example, for those universities in regions where there is many first nation people, multiculturalism and diversity become more present and relevant compared to other competences. For another group of universities, the competences declared as part of their seal are more pragmatic. In this way, it surprises to find among the seal competences some transversal ones that make part of the seal in most universities, making their profile less unique.

Finally, in the minority of universities, it was observed that all generic competences were equivalent to the institutional seal, meaning that outside of their seal, they did not consider any other competences of importance.

These modalities of curricular implementation of the formative seal give account of the relevance that universities attribute to the graduation profile component, in which all institutions link generic competences. Meaning, there is not a single university that does not consider generic competences in their seal.

\section{IV.1.3. Modality of curricular implementation of generic skills}

In general, there is no explicit adherence to a specific theoretical approach in the curricular implementation of generic skills. Institutions have adopted the student-centered approach to teaching-learning as a predominant paradigm, which translates into the use of active methodologies and the definition of learning achievements or outcomes. For example, it was observed that institutions tend to use methodologies such as projects, learning based in problems, simulations, teamwork, etc. On the other hand, most of the evaluation instances were inside curricular activities that belong to the general formative programs. Some universities have opted for evaluations integrated on the courses when these are disciplinary. Others have chosen to use landmarks through assigning integrated activities. These are usually placed by the end of formative cycle, becoming a sort of intermediate evaluation of graduation profile. 
Only the minority of universities apply diagnostics to measure how the students are regarding these competences when they first arrive.

As for the curricular design, only some institutions claim to have a competences curriculum in the classical sense (modular and progressive), the rest declare a curriculum based on skills (generic and specific) and expressed in learning achievements or learning outcomes.

All universities declare that generic skills are included in the graduation profile of undergraduate curricula. In this area, the institutions have adopted the guidelines agreed by the Council of Rectors of Chilean Universities ${ }^{40}$ regarding curricular innovation. These orientations have a pragmatic rather than theoretical character, in the sense that higher education institutions respond functionally to the requirements of the labor market. Meaning, universities make periodic interviews to employers to know which are the labor market current needs, so they can construct a profile that allows easy insertion once graduated. These interviews are usually done biannually and are part of the mechanisms universities have to establish a link with the labor market.

On the other hand, the process of curricular implementation has had greater complexity in those universities whose academic offer is wider and more diverse than those with a limited academic offer and less heterogeneous in the discipline. Amon the 18 traditional universities, 13 of them count with wide offer of programs in almost all disciplines. The other five count with a more limited offer.

Regarding the modalities used by the institutions to implement the generic competences in the curriculum, three variants are distinguished. The information provided by each institution allowed the team of researchers to classify the modalities of implementation according to what the literature presents. These are (1) in specific subjects (focused), (2) in transversal subjects, or (3) in a combination of both (mixed). These modalities have been described by Yañiz and Villardón, ${ }^{41}$ Robley, Whittle and Murdoch-Eaton ${ }^{42}$ and Bennett, Dunne and Carre. ${ }^{43}$

${ }^{40}$ Cluster of public and private-owned Chilean universities that were founded before 1980 .

${ }^{41}$ Concepción Yániz, Lourdes Villardón, "Modalidades de evaluación de competencias genéricas en la formación universitaria", Didac, 60, (2 de julio de 2012), 17-18.

${ }^{42}$ Will Robley, Sue Whittle \& Deborah Murdoch-Eaton, "Mapping generic skills curricula: a recommended methodology" Journal of Further and Higher Education, 29, no. 3 (2005), 221-231, https://doi.org/10.1080/03098770500166801.

${ }^{43}$ Neville Bennett, Elisabeth Dunne and Clive Carre, "Skill Development in Higher Education and Employment" In Differing Visions of a Learning Society Vol 1: Research Findings, edited by Coffield Frank. (Bristol, UK: Bristol University Press, 2000), 105- 138. 
Most public institutions have opted for the mixed modality. This option is to ensure that the generic competences are developed during the entirety of the formative process.

Focused: The generic skills are explained in specific subjects of the curriculum, dedicated exclusively to their development. These are the socalled Comprehensive Training Programs, Fundamental Training or General Training, which congregate a set of subjects of a transversal nature to all the careers of the institution.

These transversal subjects reach the highest level of achievement for generic skills. They usually respond to training in the institutional seal or to the generic skills of the graduation profile.

One of the difficulties of this implementation is related to the academic load that is added to the curricula in relation to the disciplinary subjects. It implies that the career must grant hours and credits for these curricular activities, which have a lower assessment than the subjects of the discipline in the opinion of the interviewees. This situation creates a tension that necessarily implies installing a process of curricular "negotiation".

The main questioning from literature to this type of implementation is that generic skills are not transferred to other learning spaces, since they are limited only to certain subjects, without offering the student the possibility of developing it in a systematic process and in intensity levels that allow its appropriation.

The positive thing about this modality is that it facilitates the management and evaluation of generic skills due to the fact that they are limited to a curricular activity dedicated exclusively to their development. This modality is adopted by 2 of 13 institutions.

Transversal: Generic skills are declared in all subject programs of a program's curriculum, or in some of them. In turn, the association of generic skills with the program's curriculum can be total or partial. This means all or those that are chosen according to selection criteria are associated to the selected generic skills. These selection criteria also incorporate the levels of progression that generic skills must reach. Those generic skills that are part of the institutional seal are mandatory.

The greater complexity of this modality is related to the preparation of teachers to understand the scope of the incorporation of these skills in the subject programs. This is also true for the pedagogical training that allows the university teaching staff to use according teaching-learning methodologies.

On the other hand, generic skills are required to have a direct relationship with the subject, either through its contents and / or through methodological strategies of the teaching-learning process to promote them in its students. 
Another complexity of this modality is related to the evaluation of the achievement of generic skills when they are inserted in disciplinary subjects, which requires having a trained and aligned teaching team. This modality is adopted by 2 of 13 institutions.

Mixed: The generic competences are explained in specific subjects of the curriculum dedicated exclusively to their development and also in the disciplinary subjects. In the latter, the taxation may be total or partial, depending on the criteria that each institution has adopted. This modality can acquire three expressions.

- Mixed A: The generic skills are declared in all the subject programs of a study plan and also includes a set of specific subjects dedicated exclusively to the generic skills. It is a rigid curricular design for all the institution's programs.

- Mixed B: The generic skills are declared, according to certain criteria, only in some subject programs of a curriculum and also contemplates a set of specific subjects dedicated exclusively to the generic skills. It is a flexible curriculum design, which allows differentiation.

- Mixed C: Refers to any of the previous modalities that contemplates extracurricular activities that allow to demonstrate the acquisition of certain generic skills through a system protocolized by each institution. Extracurricular activities include volunteering, participation in congresses, student groups, employability strengthening workshops, university adaptation workshops, among others.

Most institutions have opted for Mixed A or Mixed B modalities ( 9 of 13 institutions).

The depth of development of generic skills in the training process has been established at levels of progression. That is, for each generic skill, a three-level scale is defined through learning achievements, learning outcomes, or key performances (the name depends on each institution).

Regarding the quantity of generic skills present in a subject within a curriculum, the existence of a defined number or a specific range was not verified.

\section{Discussion}

The modality of participatory commissions for the selection of generic skills used by the studied institutions coincides with that indicated by Palmer, 
Montaño and $\mathrm{Palou}^{44}$, in the sense that to choose the generic skills, the opinion of four social actors is required: a) the academic community, b) employers, c) graduates and d) professional associations. Tran Le Huu $\mathrm{Nghia}^{45}$, refers to actors as external stakeholders for the training provided in higher education, with the participation of employers, non-governmental organizations, public services, and local authorities becoming increasingly important. This is also noted by Chowdhury and Miah, ${ }^{46}$ and Jackson and Chapman. ${ }^{47}$

Regarding the number of generic skills selected by each institution, a variation between 3 and 13 generic skills was observed with an average of 6.5 per university. In this regard, Villa and Poblete ${ }^{48}$, starting from the experience of the University of Deusto recommend proposing between 8 to 10 generic skills for a curriculum of 30 subjects. It should be considered that in Europe, the duration of the programs leading to the bachelor's degree is on average less than the duration in Latin America.

Each university decides how many generic skills to assume for its graduation profiles. This decision does not have official standards, and as such, becomes self-determined. This situation adds considerable difficulties to it. Another difficulty is the negotiation that must be established with the programs to install the generic skills in the curricula. In this regard, Villa and Poblete ${ }^{49}$, recommend discussing the map of generic skills with teachers, in order to establish a direct link with the

44 Alfonso Palmer, Juan J. Montaño and María Palou, "Las competencias genéricas en la educación superior. Estudio comparativo entre la opinión de empleadores y académicos," Psicothema, 21, no. 3, (2009), 433-438.

45 Tran Le Huu Nghia, "External stakeholders' roles and factors influencing their participation in developing generic skills for students in Vietnamese universities", Journal of Education and Work 31, no. 1, (2017), 72-86, https://doi.org/10.1080/13639080.2017.13 86774.

46 Tamgid Ahmed Chowdhury, and Mohammad Khasro Miah, "Employability Skills for Entry-level Human Resources Management Positions: Perceptions of Students and Employers", Australian Journal of Career Development 25, no. 2, (2016), 55-68, https://doi. org/10.1177/1038416216658774.

${ }^{47}$ Denise Jackson and Elaine Chapman, "Non-technical Skill Gaps in Australian Business Graduates", Education + Training, 54, no. 2-3, (2012), 95-113, https://doi.org/10.1108/004 00911211210224.

${ }^{48}$ Aurelio Villa and Manuel Poblete, "Evaluación de Competencias Genéricas: Principios, Oportunidades y Limitaciones", Bordón, Revista de Pedagogía, 63, no. 1, (2011), 158, https:// recyt.fecyt.es/index.php/BORDON/article/view/28910.

49 Aurelio Villa and Manuel Poblete, "Evaluación de Competencias Genéricas: Principios, Oportunidades y Limitaciones”, Bordón, Revista de Pedagogía, 63, no. 1, (2011), 158, https:// recyt.fecyt.es/index.php/BORDON/article/view/28910. 
subjects and minimize the less relevant status for generic skills in the training process.

From another perspective, Villarroel and Bruna $^{50}$ warn about the complexity in the selection of generic skills and their integration on the different programs. This because there would be no clear consensus regarding more transversal generic skills and, therefore, their relationship may be more evident in some programs and less in others. In fact, the studied institutions have decreased the amount of generic skills that they initially selected, appealing to the real capacity for training of their students.

The demands of the labor market have been a factor considered in the graduation profiles by all the studied institutions. This finding coincides with that indicated in various studies..$^{51,52,53,54}$ The multifunctionality developed by generic skills in professional performance makes employers demand this type of higher education training. This, according to Rodríguez ${ }^{55}$, would increase the employability of graduates and improve productivity and competitiveness.

Regarding the generic skills selected by the studied universities and which have a greater convergence (effective communication, teamwork, ethics, autonomous learning and social responsibility), there is a coincidence with other studies. Delloite ${ }^{56}$ identified oral communication, commitment to work, and teamwork as the most important for improving employability. A similar result in Europe identified oral communication, teamwork, ability to

${ }^{50}$ Verónica Villarroel, \& Daniela Bruna, "Reflexiones en torno a las competencias genéricas en educación superior: Un desafío pendiente", Psicoperspectivas, 13, no. 1, (2014), 22 - 34, https://dx.doi.org/10.5027/psicoperspectivas-Vol13-Issue1-fulltext-335.

${ }^{51}$ Balcar, "Better to Invest in Hard or Soft Skills?" 453-470.

52 María Elena Cano, "La evaluación por competencias en la educación superior", Revista de Currículum y Formación del Profesorado, 12, no. 3, (2008), 1-16, https://www.ugr. es/ recfpro/rev123COL1.pdf.

${ }_{53}$ Marta Haro. "Actividades que ayudan a desarrollar las competencias genéricas del ámbito educativo, in Competencias genéricas y transversales de los titulados, Ed. ICE de la Universidad de Zaragoza (Zaragoza: Universidad de Zaragoza, 2008), 86-90, https://ice.unizar. es/sites/ice.unizar.es/files/users/leteo/publicaciones/col._documentos_08.pdf.

${ }^{54}$ Concepción Yaniz, "Planificar la enseñanza universitaria para el desarrollo de competencias", Revista Educatio Siglo XXI, no. 24, (España, 2006), 17-34, https://revistas. um.es/educatio/article/view/151.

${ }^{55}$ Hernando Rodríguez Zambrano, "El paradigma de las competencias hacia la educación superior”, Revista Facultad de Ciencias Económicas: Investigación y Reflexión, vol. XV, no. 1, (Universidad Militar Nueva Granada Bogotá, Colombia, junio, 2007), 152.

56 Deloitte, "Global Human Capital Trends", 2017, (Accessed November 1, 2019), https://www2.deloitte.com/global/en/pages/human-capital/articles/introduction-humancapital-trends.html. 
think innovatively, and work under pressure as the most relevant generic skills. ${ }^{57,58}$

The sequence that the generic skills assume in the curricula of the public universities, only has a logic of progression in levels of achievement, which in the majority are quantified to a third level, using taxonomies of learning that go from knowing to applying.

Villa and Poblete ${ }^{59}$ suggest including generic instrumental skills in subjects of the first years, and in the following years interpersonal and systemic skills (teamwork, leadership, among others). This proposal is based on the student body's academic maturity and its ability to correctly assess and develop interpersonal and / or systemic skills at the higher levels.

However, it is interesting what Kuhn and Weinberger ${ }^{60}$, who studied the return of wages in the leadership skills in the United States, pointed out. The authors found that, in higher education students, there is a greater probability of assuming managerial positions when at the school stage they have directed sports or student teams and have also self-assessed as leaders. This confirms that the development of generic skills is a continuous process over time and that the more access people have to experiences that allow them to train these or other skills or abilities, the greater the probability of appropriating them.

As for the institutional seal, it is valid to ask what implications does it have for the training process? What value does it add to training? An explanatory hypothesis is that the massification of institutions of higher education has generated the need for differentiation between institutions. This has materialized in the so-called "formative stamps", which could add competitive advantages, given the "commoditization of higher education". Miller ${ }^{61}$ has identified and described this trend.

The institutional seal in higher education institutions has generated an important effort at the curricular level, which has resulted in the creation of

57 Andrews and Higson, "Graduate Employability”, 411-422.

${ }^{58}$ Enric Corominas, "Competencias genéricas en la formación universitaria", Revista de Educación, 325, (2001), 299-321, http://www.educacionyfp.gob.es/dam/jcr:1ba9ac11-1d4a4679-845f-b0f77109a23f/re3252109962-pdf.pdf.

59 Aurelio Villa Sánchez and Manuel Poblete Ruiz, "Evaluación de competencias genéricas: principios, oportunidades y limitaciones", Bordón Revista de Pedagogía, ISSN 0210-5934, ISSN-e 2340-6577, 63, no 1, (2011) 158.

${ }^{60}$ Peter Kuhn and Catherine Weinberger, "Leadership Skills and Wages", Journal of Labor Economics, 23, no. 3, (2005), 395-436, https://doi.org/10.1086/430282.

${ }^{61}$ Brian Miller, "Skills for sale: what is being commodified in higher education?" Journal of Further and Higher Education, 34, no. 2 (2010), 199-206, https://doi. org/10.1080/03098771003695460. 
specific subjects for its development. This effort has been called focused implementation..$^{62}$ The incorporation of specific subjects, unusual in past decades, is today a component of curricular designs whose purpose is to materialize the university mission.

The main questioning of the modality of focused implementation is that generic skills are not transferred to other learning spaces, limited to the curricular activity that has been specially designed for its development. This criticism is based on the fact that the knowledge of a generic skill is not limited to a particular situation or discipline, but that its main attribute is its integrative character and the ability to be transferred to different situations and disciplines.$^{63}$ The advantage of the focused modality is that it facilitates management control and evaluation in the student body.

Special mention deserves the teaching performance, since those who teach in higher education, for the most part, do not have pedagogical training and therefore privilege disciplinary learning because that is the one they excel in. In this way, training in generic skills goes to the background, basically due to teachers' lack of knowledge about tools with which to develop them. Then it happens that the knowledge and methodologies to prosecute the teaching-learning process, are acquired in the teaching performance itself, spontaneously, by trial and error ${ }^{64}$ replicating the same methods by which they learned.

Hence, the importance that higher education institutions have led to the pedagogical improvement of their academics, settling in as a need aimed at safeguarding the quality of teaching. Bain ${ }^{65}$ in an effort to identify best practices of university teachers, highlights the importance of promoting intellectual and personal development with evidence, specifying that quality learning is one that manages to develop intellectual and personal students.

${ }^{62}$ Concepción Yañiz and Lourdes Villardón, "Modalidades de evaluación de competencias genéricas en la formación universitaria". Didac. Evaluación de los aprendizajes, 60, (2012), 17.

${ }^{63}$ Benilde García, Javier Loredo, Edna Luna and Mario Rueda, "Modelo de evaluación de competencias docentes para la evaluación media y superior", Revista Iberoamericana de Evaluación Educativa 1, no. 3, (2008), 96-108, http://www .rinace.net/riee/numeros/vol1num3_e/art8.pdf

${ }^{64}$ Fernando Moscoso and Adela Hernández, "La formación pedagógica del docente universitario: un reto del mundo contemporáneo," Revista Cubana de Educación Superior, 34, no. 3 (2015), 140-154, http://scielo.sld.cu/scielo.php?script=sci_arttext\&pid=S025743142015000300011\&lng=es\&tlng=es.

${ }^{65}$ Ken Bain, "Lo que hacen los mejores profesores universitarios", traducción Oscar Barberá, Universitat de Valencia, ISBN 978-84-370-6669-1 (2007), 103-111. 
This author's affirmation confirms the contribution of generic skills in the integral education of higher education students. ${ }^{66,67}$

\section{Conclusions}

There is strong evidence regarding the need to develop generic skills in higher education. Today, it becomes an unavoidable component of academic training given its integrative, transferable, and empowering nature of disciplinary learning, as well as the employability of graduates.

Despite the above, the institutions face a complex process when selecting generic skills. Since there are no standards, differences in the valuation that employers, academics, and graduates attribute to each generic skill are appreciated. The convergence between the actors involved necessarily requires adopting agreements.

Both in Chile and in other countries, the higher influence given to the opinion of employers when selecting generic skills is verified, understanding that the institutions expect to respond to the real and current needs of the labor market.

The Chilean public universities, although they converge in a subset of generic skills, have not reached this conclusion by intentional interinstitutional agreement.

Regarding the institutional seal, it is found that this corresponds to a fraction of the generic skills, which is closely linked to materialize the mission of each university in the training process, thus providing a component that is its own and distinctive.

Both in the selection of generic skills and in the institutional seal, an interesting debate is opened towards a possible space of convergence, since the new regulations for the public universities establish certain formative attributes in the student's graduation profile. This debate should also consider future trends in the labor market.

The evidence provided in this study demonstrates that the amount of generic skills that an institution assumes in its discharge profile has been a dynamic process, whose tendency has been to decrease its number. The explanation of this action is the actual capacity that the institution has to

${ }^{66}$ María Elena Cano, "La evaluación por competencias en la educación superior, Profesorado", Revista de Currículum y Formación del Profesorado, 12, no. 3 (2008), 1-16.

${ }^{67}$ Concepción Yañiz, "Las competencias en el currículo universitario: implicaciones para diseñar el aprendizaje y para la formación del profesorado" Revista de Docencia Universitaria, Monográfico $1^{\circ}$ (2008), 18, http://www.redu.um.es/Red_U/m1/. 
effectively form the generic skills in its students, considering both the disciplinary diversity and the heterogeneity of its student population.

On the other hand, the modality of curricular implementation of generic skills is a decision that faces advantages and difficulties. Among the most critical aspects, teachers' performance is identified in the development of generic skills and in the conviction of their importance, for which the training of the teaching staff becomes a necessity.

The progressive character in the learning and appropriation of the generic skills in the student body is another relevant conviction of the universities, since it is not possible that skills such as effective communication or teamwork are acquired in a single curricular activity or event of a student's curriculum. This learning is systematic and progressive in intensity levels.

Finally, although it may seem repetitive, it is important to recognize the dynamic nature of generic skills, particularly because of the context of speed in the scientific, technological and social changes of today's world. It implies and demands flexible curricular designs, capable of adapting and responding to the evolutionary dynamism of society.

The process is still happening and results in terms of satisfaction or return of graduates, or prestige for the institution are complex to isolate. The relationship between generic skills definition or implementation method with any of these factors is not yet well established. While generic skills face constant change in terms of their demand in the labor market, methods of implementation can have a more stable nature, yet it is not possible to say if there is a correct or superior method as there is no evidence that can safely link a method with acquisition of generic skills in higher education.

\section{Bibliography}

Abaida, Abdellah, Youssef Lakrari, and Abdeljabbar Abdouni. "An examination of the relationship between competences and wages of higher education graduates: Evidence from Morocco". Tuning Journal for Higher Education 5, no. 1, 2017, http://dx.doi .org/10.18543/tjhe-5(1)-2017pp75-100.

Amaral, Alberto, Guy Neave, Christine Musselin, and Peter Maassen. European Integration and de Governance of Higher Education and Research, 2009, 3-58.

Andrews, Jane and Helen Higson, "Graduate Employability, 'Soft Skills' Versus 'Hard' Business Knowledge: A European Study." Higher Education in Europe 33, no. 4, 2008, https://doi.org/10.1080/03797720802522627.

Bain, Ken. Lo que hacen los mejores profesores universitarios. Translated by Oscar Barberá. Valencia: Universitat de Valencia, 2007.

Balcar, Jiří. "Is it Better to Invest in Hard or Soft Skills?" The Economic and Labour Relations Review 27, no. 4, 2016, https://doi.org/10.1177/1035304616674613. 
Beneitone, Pablo, César Esquetini, Julia González, Maida Marty Maletá, Gabriela Siufi and Robert Wagennar. Informe Final del Proyecto Tuning América Latina: Reflexiones y perspectivas de la Educación Superior en América Latina. Bilbao, España: Universidad de Deusto and Universidad de Groningen, 2007.

Bennett, Neville; Elisabeth Dunne and Clive Carre. "Skill Development in Higher Education and Employment." In Differing Visions of a Learning Society. Research Findings Volume 1, edited by Frank Coffield, Bristol, UK: Bristol University Press, 2000.

Bughin, Jacques, Eric Hazan, Sudan Lund, Peter Dahlström, Anna Wiesinger, \& Amresh Subramaniam. Skill Shift Automation and the Future of the Workforce. McKinsey Global Institute, 2018, https://www.mckinsey.com/ /media/ McKinsey/Featured\%20Insights/Future\%20of\%20Organizations/Skill\%20 shift $\% 20$ Automation $\% 20$ and $\% 20$ the $\% 20$ future $\% 20$ of $\% 20$ the $\% 20$ workforce/ MGI-Skill-Shift-Automation-and-future-of-the-workforce-May-2018.ashx.

Cano, María Elena. "La evaluación por competencias en la educación superior," Revista de Currículum y Formación del Profesorado 12, no. 3, 2008, https:// www.ugr.es/ recfpro/rev123COL1.pdf.

Carnevale, Anthony P., Cheah Ban and Jeff Strohl. Hard Times: College Majors, Unemployment and Earnings: Not All College Degrees Are Created Equal. Georgetown: Georgetown University, 2013, http://hdl handle.net/10822/559308

Clarke, Marilyn. "Rethinking Graduate Employability: The Role of Capital, Individual Attributes and Context." Studies in Higher Education 43, no. 11, 2017, https://doi.org/10.1080/03075079.2017.1294152.

Comisión Nacional de Acreditación, Criterios para la acreditación de carreras. Santiago, Chile: Comisión Nacional de Acreditación, 2016, https://www. cnachile.cl/Criterios\%20y\%20Procedimientos/DJ\%20009-4\%20Criterios.pdf.

Corominas, Enric. "Competencias genéricas en la formación universitaria," Revista de Educación 325, 2001, http://www.educacionyfp.gob.es/dam/jcr:1ba9ac111d4a-4679-845f-b0f77109a23f/re3252109962-pdf.pdf.

Crossman, Johanna Elizabeth and Marilyn Clarke. "International experience and graduate employability: stakeholder perceptions on the connection". Higher Education, 59, 2010, https://doi.org/10.1007/s10734-009-9268-z.

Chowdhury, Tamgid Ahmed and Mohammad Khasro Miah. "Employability Skills for Entry-level Human Resources Management Positions: Perceptions of Students and Employers." Australian Journal of Career Development 25, no. 2, 2016, https://doi.org/10.1177/1038416216658774.

Deloitte, "Global Human Capital Trends", 2017, Accessed November 1, 2019, https://www2.deloitte.com/global/en/pages/human-capial/articles/introductionhuman-capital-trends.html.

Díaz-Barriga, Ángel, “Competencias en educación. Corrientes de pensamiento e implicaciones para el currículo y el trabajo en el aula", Revista Iberoamericana de Educación Superior (ries), México, unam-iisue/Universia, vol. II, no. 5, 2011, http://ries.universia.net/index.php/ries/article/view/126. 
Fenesi, Bárbara and Faria Sana. "What is your degree worth? The relationship between post-secondary programs and employment outcomes", Canadian Journal of Higher Education 45, no. 4, 2015, http://journals.sfu.ca/cjhe/index. php/cjhe/article/view/183604/pdf_48.

García, Benilde, Javier Loredo, Edna Luna and Mario Rueda, "Modelo de evaluación de competencias docentes para la evaluación media y superior," Revista Iberoamericana de Evaluación Educativa 1, no. 3, 2008, http://www .rinace.net/ riee/numeros/vol1-num3_e/art8.pdf.

González, Julia, Robert Wagenaar and Pablo Beneitone. "Tuning - América Latina: un proyecto de las universidades" Revista Iberoamericana de Educación, 35, 2004, https://rieoei.org/historico/documentos/rie35a08.pdf.

Harris Richard and Ormond Barbara, Historical knowledge in a knowledge economy - what types of knowledge matter?, Educational Review, 71, no. 5, 2018, https:// doi.org/10.1080/00131911.2018.1462764.

Haro, Marta. "Actividades que ayudan a desarrollar las competencias genéricas del ámbito educativo, in Competencias genéricas y transversales de los titulados, Ed. ICE de la Universidad de Zaragoza, Zaragoza: Universidad de Zaragoza, 2008, https://ice.unizar.es/sites/ice.unizar.es/files/users/leteo/publicaciones/ col._documentos_08.pdf.

Harvey, Lee. "Defining and Measuring Employability", Quality in Higher Education 7, no. 2, 2010, http://dx.doi.org/10.1080/13538320120059990.

Harvey, Lee, William Locke, and Alistair Morey. Enhancing employability, recognizing diversity Making links between higher education and the world of work, London: Universities UK, 2002.

Heckman, James J., Jora Stixrud and Sergio Urzúa. "The Effects of Cognitive and Noncognitive Abilities on Labor Market Outcomes and Social Behavior", Journal of Labor Economics, 24, no.3, 2006, http://www.jstor.org/ stable/10.1086/504455.

Hurrel, Scott A. "Rethinking the soft skills deficit blame game: Employers, skills withdrawal and the reporting of soft skills gaps". Human Relations 69, no. 3, 2016.

Jackson, Denise and Elaine Chapman. "Non-technical Skill Gaps in Australian Business Graduates," Education + Training 54, no.2-3, 2012, https://doi. org/10.1108/00400911211210224.

Kalfa, Senia and Lucy Taksa, "Cultural Capital in Business Higher Education: Reconsidering the Graduate Attributes Movement and the Focus on Employability" Studies in Higher Education 40, no. 4, 2015, https://doi.org/10. 1080/03075079.2013.842210.

Kuhn, Peter and Catherine Weinberger. "Leadership Skills and Wages," Journal of Labor Economics 23, no. 3, 2005, https://doi.org/10.1086/430282

Ley $\mathrm{N}^{\circ}$ 20901. Diario Oficial de la República de Chile, Chile: Santiago; May 11, 2018.

Ley $\mathrm{N}^{\circ}$ 20904. Diario Oficial de la República de Chile, Chile: Santiago, May, 25, 2018. 
Lessard Claude "La réforme du curriculum québécois et son difficile atterrissage", Revue internationale d'éducation de Sèvres, no. 73, 2016, http://journals. openedition.org/ries/5623.

Miller, Brian. "Skills for sale: what is being commodified in higher education?" Journal of Further and Higher Education 34, no. 2, 2010, https://doi. org/10.1080/03098771003695460.

Moore, Tim and Janne Morton. "The Myth of Job Readiness? Written Communication, Employability, and the 'Skills Gap' in Higher Education," Studies in Higher Education 42, no. 3, 2017, https://doi.org/10.1080/03075079.2015.1067602.

Monckeberg, María O. Con fines de lucro. La escandalosa historia de las universidades privadas de Chile. Santiago, Chile: Debate, 2013.

Moscoso, Fernando and Adela Hernández. "La formación pedagógica del docente universitario: un reto del mundo contemporáneo," Revista Cubana de Educación Superior 34, no. 3, 2015, http://scielo.sld.cu/scielo.php?script=sci_ arttext\&pid=S0257-43142015000300011\&lng=es\&tlng=es.

OECD, The future of education and skills. Education 2030. OCDE, 2018, https://www. oecd.org/education/2030/E2030\%20Position\%20Paper\%20(05.04.2018).pdf.

Palmer, Alfonso, Juan J. Montaño and María Palou. "Las competencias genéricas en la educación superior. Estudio comparativo entre la opinión de empleadores y académicos," Psicothema 21, no. 3, 2009.

Pey, Roxana and Sara Chauriye. Innovación Curricular en las Universidades del Consejo de Rectores 2000 - 2010. Santiago, Chile: Consejo de Rectores, 2012. https://sct-chile.consejoderectores.cl/documentos_WEB/Innovacion_ Curricular/2.Informe_INNOVACION_CURRICULAR.pdf.

Robley, Will, Sue Whittle and Deborah Murdoch-Eaton. "Mapping generic skills curricula: a recommended methodology," Journal of Further and Higher Education, 29 no. 3, 2005, https://doi.org/10.1080/03098770500166801.

Robs, John. "Education and job match: The relatedness of college major and work." Economics of Education Review 26, no. 4, 2007, https://doi.org/10.1016/j. econedurev.2006.08.003.

Rodríguez Zambrano, Hernando. "El paradigma de las competencias hacia la educación superior" Revista Facultad de Ciencias Económicas: Investigación y Reflexión, 15 no. 1, 2007.

Rychen, Dominique and Laura H. Salganik (ed.). Key Competences for a Successful Life and Well-Functioning Society. Göttingen, Germany: Hogrefe \& Huber Publishers, 2003.

Scott, Fraser J., Pauline Connell, Linda A. Thomson and Debra Willison. "Empowering students by enhancing their employability skills", Journal of Further and Higher Education 43, no. 5, 2017, https://doi.org/10.1080/030987 7X.2017.1394989.

Sepúlveda Obreque, Alejandro; Opazo Salvatierra, Margarita; Díaz-Levicoy, Danilo, Competencias sello en la universidad: promoción y evaluación en Pedagogía Básica. Cuad. Investig. Educ. Montevideo, v. 9, n. 1, 2018, http://dx.doi. org/10.18861/cied.2018.9.1.2819. 
Sin, Cristina and Guy Neave. "Employability Deconstructed: Perceptions of Bologna Stakeholders." Studies in Higher Education 41, no. 8, 2016, https://doi.org/10.1 080/03075079.2014.977859.

Suleman, Fatima and Ana María Costa. "The employability skills of graduates and employers' options in Portugal: An explorative study of anticipative and remedial strategies," Education + Training, Vol. 60, no. 9, 2018, https://doi. org/10.1108/ET-10-2017-0158.

Tran Le Huu Nghia. "External stakeholders' roles and factors influencing their participation in developing generic skills for students in Vietnamese universities," Journal of Education and Work 31, no. 1, 2017, https://doi.org/10.1080/136390 80.2017.1386774.

Villarroel, Verónica and Daniela Bruna. "Reflexiones en torno a las competencias genéricas en educación superior: Un desafío pendiente," Psicoperspectivas 13, no. 1, 2014, https://dx.doi.org/10.5027/psicoperspectivas-Vol13-Issue 1fulltext-335.

Villa, Aurelio and Manuel Poblete. "Evaluación de Competencias Genéricas: Principios, Oportunidades y Limitaciones," Bordón. Revista de Pedagogía 63, no. 1, 2011, https://recyt.fecyt.es/index.php/BORDON/article/view/28910.

World Economic Forum. The Future of Jobs Report, World Economic Forum, 2018, https://www.weforum.org/reports/the-future-of-jobs-report-2018

Yañiz, Concepción. "Las competencias en el currículo universitario: implicaciones para diseñar el aprendizaje y para la formación del profesorado" Red U. Revista de Docencia Universitaria. Num. Monográfico $1^{\circ}$ REDU. Revista de Docencia Universitaria, 2008, http://www.redu.um.es/Red_U/m1/

Yániz, Concepción and Lourdes Villardón. "Modalidades de evaluación de competencias genéricas en la formación universitaria,” Didac, 60, 2012.

\section{About the authors}

LUIS SANDOVAL (lsandoval@utem.cl) received his degree in political science from Pontificia Universidad Católica de Chile. His interest areas are educational policies, impact evaluation, higher education and employment. He has worked in various managerial positions in Chilean universities including Director of Undergraduate Studies and Director of Graduate Studies. At present, he works in the Universidad Tecnológica Metropolitana. ORCID: http://orcid.org/00000001-9452-4945.

MARÍA ORMAZÁBAL (mormazabal@utem.cl) received her degree in education from Universidad de Chile. Her interest areas are educational policies, generic competences, impact evaluation, higher education and employment. At present, she works in the Universidad Tecnológica Metropolitana (Chile). 


\title{
The Generic skills challenge for higher education institutions: Experience of public universities in Chile
}

\author{
Luis Sandoval and María Ormazábal
}

doi: http://dx.doi.org/10.18543/tjhe-8(2)-2021pp55-83

\section{Copyright}

Copyright for this article is retained by the Publisher. It is an Open Access material that is free for full online access, download, storage, distribution, and or reuse in any medium only for noncommercial purposes and in compliance with any applicable copyright legislation, without prior permission from the Publisher or the author(s). In any case, proper acknowledgement of the original publication source must be made and any changes to the original work must be indicated clearly and in a manner that does not suggest the author's and or Publisher's endorsement whatsoever. Any other use of its content in any medium or format, now known or developed in the future, requires prior written permission of the copyright holder. 